\title{
Orthogonal Test Design for the Optimization of Preparation of Steel Slag-Based Carbonated Building Materials with Ultramafic Tailings as Fine Aggregates
}

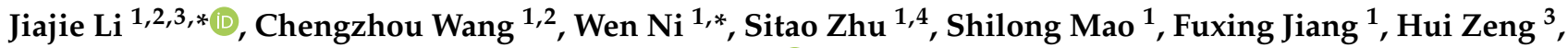 \\ Xikui Sun ${ }^{4}$, Bingxiang Huang ${ }^{2}$ and Michel Hitch ${ }^{5, * \mathbb{D}}$
}

check for updates

Citation: Li, J.; Wang, C.; Ni, W.; Zhu, S.; Mao, S.; Jiang, F.; Zeng, H.; Sun, X.; Huang, B.; Hitch, M. Orthogonal Test Design for the Optimization of Preparation of Steel Slag-Based Carbonated Building Materials with Ultramafic Tailings as Fine Aggregates. Minerals 2022, 12, 246. https://doi.org/10.3390/ $\min 12020246$

Academic Editors: Carlos Hoffmann Sampaio, Weslei Monteiro Ambros and Bogdan Grigore Cazacliu

Received: 12 January 2022

Accepted: 13 February 2022

Published: 15 February 2022

Publisher's Note: MDPI stays neutral with regard to jurisdictional claims in published maps and institutional affiliations.

Copyright: (C) 2022 by the authors. Licensee MDPI, Basel, Switzerland. This article is an open access article distributed under the terms and conditions of the Creative Commons Attribution (CC BY) license (https:// creativecommons.org/licenses/by/ $4.0 /)$.
1 Key Laboratory of Ministry of Education for Efficient Mining and Safety of Metal Mines, School of Civil and Resource Engineering, University of Science and Technology Beijing, No. 30 Xueyuan Road, Haidian District, Beijing 100083, China; wangchengzhou1996@163.com (C.W.); zhusitao@ustb.edu.cn (S.Z.); maoshil@126.com (S.M.); jiangfuxing1@163.com (F.J.)

2 State Key Laboratory of Coal Resources and Safe Mining, China University of Mining and Technology, No. 1 University Road, Xuzhou 221116, China; huangbingxiang@cumt.edu.cn

3 Shandong Iron and Steel Group Co., Ltd., No. 2000 Shunhua Road, Gaoxi District, Jinan 250101, China; zh13863458091@163.com

4 Shandong Energy Group Co., Ltd., No. 10777 Jingshi Road, Jinan 250014, China; sunxikui@sina.com

5 Western Australian School of Mines: Minerals, Energy and Chemical Engineering, Curtin University, P.O. Box U1987, Perth, WA 6845, Australia

* Correspondence: jiajieli@ustb.edu.cn (J.L.); niwen@ces.ustb.edu.cn (W.N.); michael.hitch@curtin.edu.au (M.H.)

\begin{abstract}
The high carbonation potential makes ultramafic tailings ideal aggregates for carbonated building materials. This paper investigates the preparation condition of ultramafic tailings and steel slag through orthogonal experiments. The results show that compressive strength has a positive exponential correlation with the $\mathrm{CO}_{2}$ uptake of the carbonated compacts. The optimized conditions include a slag-tailings ratio of 5:5, a carbonation time of $12 \mathrm{~h}$, a grinding time of $0 \mathrm{~min}$, and a watersolid ratio of 2.5:10, when the compressive strength of the carbonated compacts reaches $29 \mathrm{MPa}$ and the $\mathrm{CO}_{2}$ uptake reaches $66.5 \mathrm{mg} \mathrm{CO} / \mathrm{g}$. The effects on the compressive strength ordered from high to low impact are the slag/tailings ratio, carbonation time, grinding time of steel slag, and water-solid ratio. The effects on the $\mathrm{CO}_{2}$ uptake ordered from high to low impact are the slag-tailings ratio, water-solid ratio, carbonation time, and grinding time of steel slag. A high water-solid ratio hinders the early carbonation reactions, but promotes the long-term carbonation reaction. Steel slag is the main material being carbonated and contributes to the hardening of the compacts through carbonation curing at room temperature. Ultramafic tailings assist steel slag in hardening through minor carbonation and provide fibrous contents. The obtained results lay a solid foundation for the development of tailings-steel slag carbonated materials.
\end{abstract}

Keywords: ultramafic tailings; steel slag; carbonation curing; orthogonal test; building materials

\section{Introduction}

Human activities release a large amount of $\mathrm{CO}_{2}$ and cause serious climate problems, such as global warming [1]. The whole-atmosphere $\mathrm{CO}_{2}$ concentration has reached $414.5 \mathrm{ppm}$ as of November 2021 at an increasing rate of $2.2 \mathrm{ppm}$ per year [2]. At the same time, the global temperature increased $0.84{ }^{\circ} \mathrm{C}$ above the 20th century average in 2021 [3]. The Paris Agreement has set the goal of 'keeping a global temperature rise this century well below $2{ }^{\circ} \mathrm{C}$ above preindustrial levels' [4]. All parties must work together to find efficient methods for reducing $\mathrm{CO}_{2}$ production and adopting $\mathrm{CO}_{2}$ capture, utilization, and sequestration (CCUS) technologies. 
The construction industry is a carbon-intense industry responsible for $8 \%$ of global man-made $\mathrm{CO}_{2}$ emissions [5]. Nearly $50 \%$ of the emissions are from Portland cement production [6]. Currently, researchers are looking for suitable industrial wastes to partially or totally replace Portland cement to reduce emissions from sources and solve waste management issues from pilling and landfilling [7]. At the same time, many studies have focused on CCUS by mineral carbonation as a means to produce construction materials, which could reintegrate those emissions into the final products [8]. During the process, the solid wastes were mixed with water, molded by compression, and cured in the presence of $\mathrm{CO}_{2}$, which resulted in a rapid strength gain in the carbonate cementitious system [9]. The carbonated building materials are environmentally benign (i.e., $\mathrm{pH}$ neutral and heavy metal fixation) with good durability (i.e., wear resistance, corrosion resistant, and frost-thaw resistant) $[10,11]$. Carbonated materials have already been commercialized in non-load bearing structures, such as roads, square blocks, flower beds, artificial reefs, and walls in prefabricated buildings [12-15]. The worldwide application of carbonation curing technology could potentially reach annual revenues of \$1 trillion and storage of 3-6 Gt of $\mathrm{CO}_{2}[16]$.

Steel slag, produced from the steel-making process, is one of the most suitable candidates for CCUS, considering its availability and mineralogy. Each ton of manufactured steel generates approximately $150-200 \mathrm{~kg}$ of steel slag [17]. In 2019, the world crude steel production was $1869.9 \mathrm{Mt}$ [18]. The annual production rate of steel slag was approximately 280-374 Mt. Steel slag has a mineral composition that is similar to Portland cement; however, its low hydration activity and existence of unstable phases (such as free lime and $\mathrm{MgO}$ ) limit its application as a replacement for Portland cement or aggregates [19]. Carbonation curing could neutralize free lime and harden steel slag compacts in a short time, which overcomes all the disadvantages of steel slag under traditional standard curing [20].

Recently, many researchers have studied the mechanism of carbonation curing on steel slag $[21,22]$. Steel slag contains $C_{2} S$ and $C_{3} S$, which have both carbonation and hydration characteristics. Scholars generally believe that water could help to dissolve $\mathrm{CO}_{2}$ and $\mathrm{Ca}^{2+}$ in steel slag, which accelerates the carbonation process (reaction 1). Additionally, water reacts with the steel slag and forms a C-S-H gel. The carbonation rate of C-S-H gel (reaction 2) is faster than that of non-hydrated calcium silicates. The carbonation products encapsulate and cement the steel slag particles and fill the gap between the particles, which improves the compactness of the test block and hardens the steel slag carbonated material [15]. The cementitious activity is higher when a low $\mathrm{Ca} / \mathrm{Si}$ ratio $\mathrm{C}-\mathrm{S}-\mathrm{H}$ gel and $\mathrm{CaCO}_{3}$ collaborate.

$$
\begin{gathered}
\mathrm{Ca}^{2+}+\mathrm{CO}_{3}{ }^{2-} \rightarrow \mathrm{CaCO}_{3} \\
\mathrm{C}-\mathrm{S}-\mathrm{H}+\mathrm{CO}_{2} \rightarrow \mathrm{CaCO}_{3}+\mathrm{C}-\mathrm{S}-\mathrm{H}(\text { low } \mathrm{C} / \mathrm{S})
\end{gathered}
$$

To improve the performance of carbonated steel slag building materials, studies have optimized various factors, including the physical and chemical properties of raw materials (i.e., the type of steel slag [23-25], particle size [26,27], and chemical additives [28-30]), molding conditions (i.e., water content [31] and compacting pressure [32]), and carbonation curing conditions (i.e., $\mathrm{CO}_{2}$ partial pressure [33], curing time [34], temperature [32], and humidity [35]). All these factors affect the carbonation reaction kinetics of steel slag, control the micromorphology of carbonated products, and affect the compressive strength of carbonated products [22].

The only drawback of carbonated steel slag as a building material is its high density. A density of $3.1-3.6 \mathrm{~g} / \mathrm{cm}^{3}$ is too high to use as a common building material. Additionally, a high density increases transportation costs and shortens its application distance. The addition of light tailings as fine aggregates has been an effective strategy to reduce the density and cost of building materials. Proper tailings would contribute to the hardening of concrete. For example, iron ore tailings, with an abundance of $\mathrm{SiO}_{2}$, have been successfully used as siliceous materials in autoclaved aerated concrete [36]. 
Ultramafic tailings may be suitable for carbonated steel slag materials. Ultramafic tailings from chrysotile, nickel, chromium, diamond, and platinum group element (PGE) mines contain a large amount of magnesium silicates (i.e., olivine, serpentine), which are favored for CCUS as well [37-39]. The annual production of ultramafic tailings could potentially store approximately $1.5 \%$ of annual global $\mathrm{CO}_{2}$ emissions [40]. Unluer and Al-Tabbaa found that serpentine could replace $\mathrm{MgO}$ under carbonation curing without compromising performance [41]. The application of ultramafic tailings as fine aggregates in carbonated steel slag material would have a positive effect on $\mathrm{CO}_{2}$ uptake, as well as strength development. However, how ultramafic tailings aggregates affect the carbonate cementitious system has not been studied.

This paper optimizes the preparation conditions of carbonated tailings-steel slag material by orthogonal testing. Range analysis and direct analysis of the orthogonal tests were carried out to study the effects of the slag-tailings ratio, water-solid ratio, carbonation time and steel slag grinding time on the $\mathrm{CO}_{2}$ uptake, and compressive strength of carbonated compacts. The chemical, microstructural, and morphological properties of optimized carbonated compacts were characterized to reveal the mechanism of carbonation curing on tailings and steel slag mixture compacts. The results from this study provide a reference for the development of carbonated building materials with ultramafic tailings as fine aggregates.

\section{Materials and Methods}

\subsection{Materials}

The ultramafic raw ore came from the Shuangjingzi Nickel deposit, Aluke'rqin Banner in Inner Mongolia, China. The mineral composition of the ultramafic tailings is similar to that of raw ore because the grade of $\mathrm{Ni}$ is $0.26 \%$. The raw ore was crushed by a two-stage jaw crusher and one-stage roller crusher and screened by a 150 mesh (106 $\mu \mathrm{m})$ Taylor sieve. The undersized sample is the ultramafic tailings for the experiments. The chemical composition is determined by X-ray fluorescence, and the results are shown in Table 1 . The ultramafic tailings contain $92.3 \%$ lizardite and $7.7 \%$ magnetite as tested by quantitative X-ray diffraction. The ultramafic tailings has an $80 \%$ passing size of $86 \mu \mathrm{m}$ a density of $2.56 \mathrm{~g} / \mathrm{cm}^{3}$, a Blaine's number of $207.92 \mathrm{~cm}^{2} / \mathrm{kg}$, and a water absorption of $0 \%$, as it was prepared under dry condition.

Table 1. The chemical composition of materials ( $w \mathrm{t} \%$ ).

\begin{tabular}{ccccccccccc}
\hline & $\mathrm{Fe}_{\mathbf{2}} \mathbf{O}_{\mathbf{3}}$ & $\mathbf{A l}_{\mathbf{2}} \mathbf{O}_{\mathbf{3}}$ & $\mathbf{S i O}_{\mathbf{2}}$ & $\mathbf{C a O}$ & $\mathbf{M g O}$ & $\mathbf{P}_{\mathbf{2}} \mathbf{O}_{\mathbf{5}}$ & $\mathbf{C}$ & $\mathbf{S}$ & LOI & Others \\
\hline Tailings & 5.13 & 0.58 & 38.00 & 1.52 & 36.08 & 0.03 & 0.16 & 0.03 & 11.50 & 6.79 \\
Steel slag & 27.6 & 5.2 & 11.63 & 37.13 & 7.5 & 1.29 & 0.41 & 0.10 & 4.24 & 4.9
\end{tabular}

Note: LOI is the loss on ignition which presents the volatile content, such as water, TOT/C is the total C tested by LECO method, and TOT/S is the total S tested by LECO method.

The coarse basic oxygen furnace (BOF) slag was provided by the Wuhan Iron and Steel Group. The coarse BOF slag was dry grounded in an experimental ball mill $(\mathrm{SM} \Phi 500 \times 500 \mathrm{~mm})$ for $30 \mathrm{~min}$. The ground BOF slag is the steel slag used in the experiment. The main components of steel slag are shown in Table 1. CaO accounts for $37 \%$ of the total weight and is the main component in steel slag. Alkalinity is the value of the mass fraction of $\mathrm{CaO}$ over the mass fraction of $\mathrm{P}_{2} \mathrm{O}_{5}$ and $\mathrm{SiO}_{2}$ [17], which represents the activity of the steel slag. The alkalinity of the steel slag is 2.87 , which falls in the range of high alkalinity [17]. The main minerals in steel slag in use are larnite $\left(\mathrm{C}_{2} \mathrm{~S}\right) 36.7 \%$, hatrurite $\left(\mathrm{C}_{3} \mathrm{~S}\right) 11.9 \%$, portlandite $\left(\mathrm{Ca}(\mathrm{OH})_{2}\right) 12.5 \%$, mayenite $\left(\mathrm{C}_{12} \mathrm{~A}_{7}\right) 4.8 \%$, srebrodolskite $\left(\mathrm{C}_{2} \mathrm{~F}\right) 17.6 \%$, and wustite $(\mathrm{FeO}) 15.9 \%$, and calcite $\left(\mathrm{CaCO}_{3}\right) 0.6 \%$. The steel slag has a density of $3.3 \mathrm{~g} / \mathrm{cm}^{3}$, a Blaine's number of $275 \mathrm{~cm}^{2} / \mathrm{kg}$. 


\subsection{Experiments}

Figure 1 is the flowchart of the experiments. First, the steel slag was mechanically activated. Then, the tailings, steel slag and water were evenly mixed and stirred. Afterwards, the mixture was put into a mold and compacted. The compacts were then demolded and placed in a carbonation chamber for curing. Finally, the compressive strength and carbon content of each carbonated compact were tested and analyzed. The microstructure of the carbonated material prepared under the optimum conditions was characterized by $\mathrm{X}$-ray diffraction (XRD), thermal gravity analysis (TGA) and scanning electron microscopy (SEM).

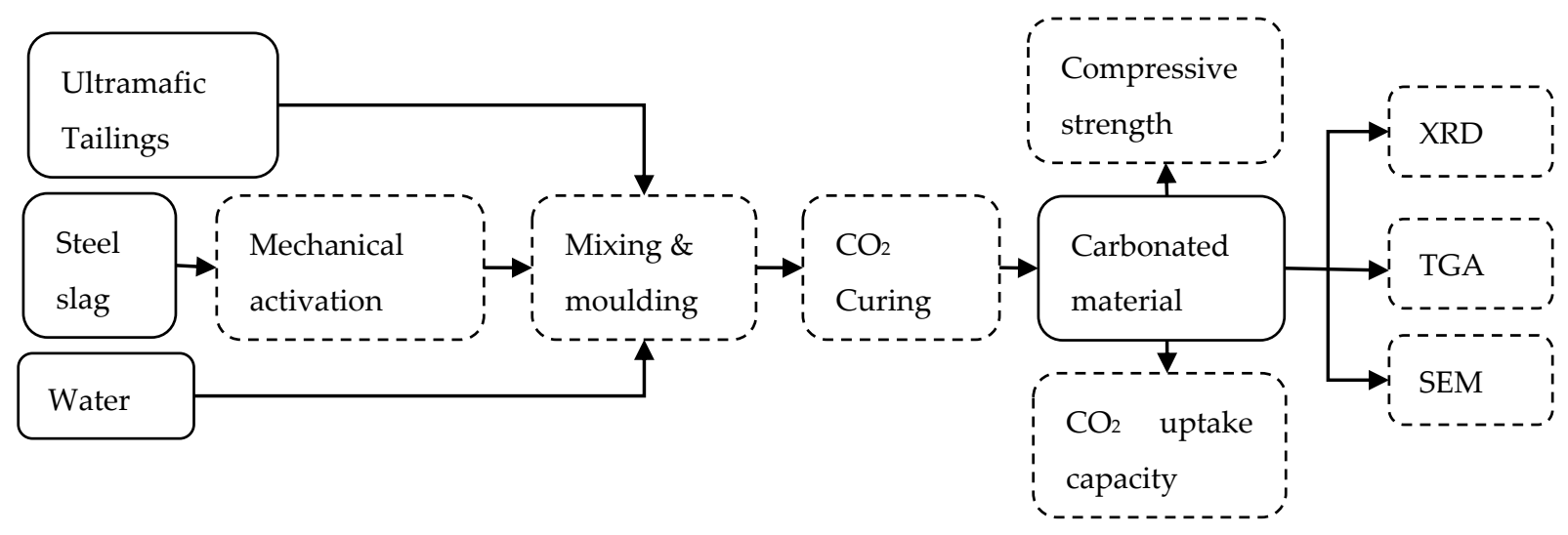

Figure 1. The experiment flowchart.

\subsubsection{Mechanical Activation}

Mechanical activation of steel slag is performed to study the effect of ultrafine grinding on the carbonation curing of steel slag. The mechanical activation test was conducted using a planetary ball mill (Omnidirectional Planetary Ball Mill ND8-4, Nanda Tianzun Electronic Co., Ltd., Nanjing, China) in the School of Metallurgical Engineering, University of Science and Technology Beijing. Four bowls of ND8-4 have planet-like movement, and the whole set rotates around a horizontal central axis along its bottom centreline with a rotational speed that is $1 / 2$ of the bowls' rotational speed. The omnidirectional movement could effectively prevent material sedimentation and grinding. The mill bowls' rotational speed was fixed at $500 \mathrm{rpm}$. In each test, steel slag was loaded with a standard number of stainless-steel balls in a $500 \mathrm{~mL}$ stainless steel mill bowl. The ball to solid weight ratio was 7:1. The steel slag was ground in dry conditions for 30,60, and $120 \mathrm{~min}$ and collected for the next tests. The Blaine's number of the steel slag after mechanical activation for 30,60 , and $120 \mathrm{~min}$ are 386,370 , and $357 \mathrm{~m}^{2} / \mathrm{kg}$, respectively. The reduction of Blaine's number with the increase of grinding time after $60 \mathrm{~min}$ is due to the aggregate of fine particles subject to prolonged grinding $[42,43]$. The Blaine's number of the mechanically active steel slags has been labeled as coarse steel slag by Wang et al. [44].

\subsubsection{Mixing and Molding}

In order to make sure of a uniform distribution of tailings and steel slag in the mixture, the ultramafic tailings, steel slag, and water were mechanically mixed for 2 min using a paste mixer at $20 \pm 5{ }^{\circ} \mathrm{C}$, and $50-70 \%$ of relative humility.

In each test, $8 \mathrm{~g}$ of moistened powder was put into a 20-mm diameter cylindrical compression stainless steel mold and compacted into individual specimens at a uniaxial load of $9 \mathrm{MPa}$ for $1 \mathrm{~min}$. The compacts were then demolded ready for carbonation cuing.

\subsubsection{Carbonation Curing}

Immediately after demolding, the specimens were placed inside the carbonation chamber (CABR-HTX12, China Academy of Building Research, Beijing, China), in which the temperature was $20 \pm 3{ }^{\circ} \mathrm{C}$, the relative humidity was kept at $70 \pm 3 \%$, and the $\mathrm{CO}_{2}$ concentration was $20 \pm 3 \mathrm{vol} \%$. The curing condition is chosen due according to the 
optimum condition for carbonation curing [12]. After a carbonation curing for 1, 3, 6, $12 \mathrm{~h}$, the carbonated compacts were collected for material characterization tests. The carbonated compacts have a diameter of $20 \mathrm{~mm}$ and height of $12 \pm 1 \mathrm{~mm}$.

\subsection{4. $\mathrm{CO}_{2}$ Uptake Capacity Calculation}

The carbon contents of the samples before and after carbonation curing were tested to calculate the $\mathrm{CO}_{2}$ uptake capacity. The carbon contents of the samples were measured using a carbon/sulphur combustion analyzer (EMIA-820 V, Horiba, Kyoto, Japan). For each test, a $0.25 \pm 0.05 \mathrm{~g}$ sample was put into a combustion crucible and covered with $1 \mathrm{~g}$ flux $(90 \%$ tungsten, $10 \%$ tin, $\mathrm{C}<0.0008 \%)$. The carbon content of the sample was determined after combustion up to $1050{ }^{\circ} \mathrm{C}$. Assuming that the carbon content in the carbonated products $\left(m_{C 1}\right)$ contains the carbon content in the raw materials $\left(m_{C 0}\right)$ and the carbon content obtained by carbonation curing $\left(m_{C}\right)$, Equation (3) is obtained based on the mass balance concept.

$$
\frac{1-m_{C 0}}{1-m_{C 1}}=\frac{m_{C 0}}{m_{C 1}-m_{C}}
$$

Therefore, $m_{C}$ can be calculated using Equation (4) [45].

$$
m_{C}=\frac{m_{C 1}-m_{C 0}}{1-m_{C 0}}
$$

The carbon contents in the original steel slag and tailings were 0.41 and $0.16 \%$, respectively. $m_{C}$ can be converted into the $\mathrm{CO}_{2}$ uptake capacity $\left(m_{\mathrm{CO}_{2}}\right)$ using Equation (5).

$$
m_{\mathrm{CO}_{2}}=\frac{m_{\mathrm{C}}}{M W_{\mathrm{C}}} \times M W_{\mathrm{CO}_{2}}
$$

where $M W_{C}$ is the molar mass of $C$, at $12 \mathrm{~kg} / \mathrm{mol}$, and $M W_{\mathrm{CO}_{2}}$ is the molar mass of $\mathrm{CO}_{2}$, at $44 \mathrm{~kg} / \mathrm{mol}$.

\subsubsection{Compressive Strength}

The compressive strength of the compact specimen before and after carbonation curing was measured in a digital pressure testing machine (YES-300, Jinan Chenda Test Machine Manufacturing Co., Ltd., Jinan, China).

\subsubsection{Quantitative X-ray Diffraction}

The mineralogy of the carbonated compacts was characterized using the Quantitative X-ray diffraction (QXRD) method. The X-ray diffraction patterns of the samples were measured using an X-ray diffractometer (D/Max-RB, Rigaku, Tokyo, Japan) equipped with a $\mathrm{Cu}-\mathrm{K} \alpha$ radiation $(20 \mathrm{kV}, 10 \mathrm{~mA})$ source, working in $2 \theta$ geometry with a recorded range from 3 to $80^{\circ}$ with a step size of $0.02^{\circ}$ in the step-scanning mode (FT $0.7 \mathrm{~s}$ ). A pattern of standard sample Si (SRM 640c) was collected using the same procedure, and was used to obtain the instrumentally broadened profile, as suggested by the US National Institute of Standards and Technology (NIST). The X-ray diffractograms were analyzed using the International Centre for Diffraction Data-base (ICDD) PDF-4 and Search-Match software $X^{\prime}$ Pert HighScore Plus (PANalytical). The X-ray powder diffraction data of the samples were refined using the Rietveld method for quantitative analysis. All the QXRD results were obtained when the weighted-profile $\mathrm{R}$ value was below $10 \%$.

\subsubsection{Thermal Gravity Analysis}

The quantitative analysis of the amount of carbonation products and hydration products in the carbonated species was tested using a TG-DTA (thermogravimetry and differential thermal analysis) analyzer (STA 449F3, Netsch, Selb, Germany). The tests were performed under an argon atmosphere with a flow rate of $20 \mathrm{~mL} / \mathrm{min}$. The heating rate was $10^{\circ} \mathrm{C} / \mathrm{min}$, and the temperature range was 50 to $1000{ }^{\circ} \mathrm{C}$. 


\subsubsection{Scanning Electron Microscopy}

The surface morphology of the carbonated species prepared under the optimum conditions was examined by a Zeiss Supra-55 field emission scanning electron microscope (SEM) (Zeiss, Oberkochen, Germany) with a secondary electron detector operating at an accelerating voltage of $15 \mathrm{kV}$. The semiquantitative chemical analysis was performed by a Zeiss Supra-55 SEM equipped with a light element energy-dispersive X-ray spectroscope (EDS). A thin Au-Pd coating was applied to the top surface of the specimen to promote the surface conductivity prior to SEM analysis.

All calculated data are the average value from 3 tests with standard error.

\subsection{Orthogonal Experiment Method}

\subsubsection{Orthogonal Experimental Design}

An orthogonal experiment was designed to optimize the preparation conditions of carbonated tailings-steel slag building materials involving multivariate and multilevel factors. The studied results of the carbonated tailings-steel slag building materials consisted of the compressive strength and $\mathrm{CO}_{2}$ uptake capacity. Therefore, the grinding time for steel slag (A), water-solid ratio (B), slag-tailings ratio (C), and carbonation time (D) were set as the four factors in the orthogonal experiment. The levels of each parameter were determined by selecting some typical values of the parameters according to literature [13]. The four levels of the mechanical activation time for steel slag were $0,30,60$, and $120 \mathrm{~min}$, with corresponding blain fineness of $275,386,370$, and $357 \mathrm{~m}^{2} / \mathrm{kg}$, respectively. The four water/solid ratios were 1:10, 1.5:10, 2:10, and 2.5:10. The four slag/tailings ratios were 0:10, $1: 9,3: 7$, and 5:5. The four levels of carbonation time were $1,3,6$, and $12 \mathrm{~h}$. The variables of each level were determined by selecting some typical values of the parameters according to the literature. Table 2 shows the orthogonal table with four factors and four levels. According to the orthogonal experimental design table of L16 $\left(4^{4}\right)$, a total of 16 themes were tested.

Table 2. Experimental schemes of orthogonal test.

\begin{tabular}{|c|c|c|c|c|c|c|c|c|}
\hline \multirow[b]{2}{*}{ Sample ID } & \multicolumn{4}{|c|}{ Levels } & \multicolumn{4}{|c|}{ Factors } \\
\hline & $\begin{array}{c}\text { A } \\
\text { (Grinding Time } \\
\text { for Steel Slag) }\end{array}$ & $\begin{array}{c}\text { B } \\
\text { (Water-Solid } \\
\text { Ratio) }\end{array}$ & $\begin{array}{c}\text { C } \\
\text { (Slag-Tailings } \\
\text { Ratio) }\end{array}$ & $\begin{array}{c}\mathrm{D} \\
\text { (Carbonation } \\
\text { Time) } \\
\end{array}$ & $\underset{(\mathrm{min})}{\mathrm{A}}$ & B & $\mathrm{C}$ & $\begin{array}{l}\text { D } \\
\text { (h) }\end{array}$ \\
\hline S1 & 1 & 1 & 1 & 1 & 0 & $1: 10$ & $0: 1$ & 1 \\
\hline S2 & 1 & 2 & 2 & 2 & 0 & $1.5: 10$ & $1: 9$ & 3 \\
\hline S3 & 1 & 3 & 3 & 3 & 0 & $2: 10$ & $3: 7$ & 6 \\
\hline S4 & 1 & 4 & 4 & 4 & 0 & $2.5: 10$ & $5: 5$ & 12 \\
\hline S5 & 2 & 1 & 2 & 3 & 30 & 1:10 & $1: 9$ & 6 \\
\hline S6 & 2 & 2 & 1 & 4 & 30 & $1.5: 10$ & $0: 1$ & 12 \\
\hline S7 & 2 & 3 & 4 & 1 & 30 & $2: 10$ & $5: 5$ & 1 \\
\hline S8 & 2 & 4 & 3 & 2 & 30 & $2.5: 10$ & $3: 7$ & 3 \\
\hline S9 & 3 & 1 & 3 & 4 & 60 & 1:10 & $3: 7$ & 12 \\
\hline S10 & 3 & 2 & 1 & 3 & 60 & $1.5: 10$ & $0: 1$ & 6 \\
\hline S11 & 3 & 3 & 4 & 2 & 60 & $2: 10$ & $5: 5$ & 3 \\
\hline S12 & 3 & 4 & 2 & 1 & 60 & $2.5: 10$ & $1: 9$ & 1 \\
\hline S13 & 4 & 1 & 4 & 2 & 120 & 1:10 & $5: 5$ & 3 \\
\hline S14 & 4 & 2 & 3 & 1 & 120 & $1.5: 10$ & $3: 7$ & 1 \\
\hline S15 & 4 & 3 & 2 & 4 & 120 & $2: 10$ & $1: 9$ & 12 \\
\hline S16 & 4 & 4 & 1 & 3 & 120 & $2.5: 10$ & $0: 1$ & 6 \\
\hline
\end{tabular}

\subsubsection{Range Analysis Method}

Range analysis was used to determine the factors' sensitivity to the experimental results according to the orthogonal experiment. Range $(R)$ is the distance between the maximum and minimum values of the data. A high $R$ value means that the factor is 
sensitive to the results, and the influence degree of the factor is high. The calculation process of the range analysis is shown in Equations (6)-(8) [46].

$$
\begin{gathered}
k_{X m}=K_{X m} / 4 \\
R_{0 X}=\max \left(k_{X 1}, k_{X 2}, k_{X 3}\right) ; R_{1 X}=\min \left(k_{X 1}, k_{X 2}, k_{X 3}\right) \\
R=R_{0 X}-R_{1 X}
\end{gathered}
$$

where, $K_{X m}$ and $k_{X m}$ are the sum and average value of the testing results, respectively, which contain the factor $X$ with $\mathrm{m}$ level. $R$ stands for the influence degree of factor $X$.

\section{Results and Discussions}

\section{1. $\mathrm{CO}_{2}$ Uptake Capacity and Compressive Strength}

In the method, 16 schemes were performed, with three repetitions for each test. Table 3 lists the compressive strength and $\mathrm{CO}_{2}$ uptake capacity of the carbonated compacts. The highest compressive strength and $\mathrm{CO}_{2}$ uptake capacity of the carbonated compacts is $29.5 \mathrm{MPa}$, and $66.5 \mathrm{mg} \mathrm{CO}_{2} / \mathrm{g}$ solid, respectively. Figure 2 shows the relationship between the compressive strength and $\mathrm{CO}_{2}$ uptake capacity of the carbonated compacts. The scatter points are basically distributed near Equation (9), with a fitting residue of $97.4 \%$. The compressive strength has a positive exponential relationship with the $\mathrm{CO}_{2}$ uptake capacity. This indicates that the compressive strength development is mainly due to the carbonation reaction. This result is in line with the results of Wang et al. [15], who found a positive linear relationship between the $\mathrm{CO}_{2}$ uptake capacity and compressive strength.

$$
y=1.84 e^{0.04 x}-0.84
$$

Table 3. The result of compressive strength and $\mathrm{CO}_{2}$ uptake capacity of carbonated material.

\begin{tabular}{ccc}
\hline Sample ID & Compressive Strength (MPa) & $\mathbf{C O}_{\mathbf{2}}$ Uptake $\mathbf{( m g} \mathbf{C O}_{\mathbf{2}}$ /g Solid) \\
\hline S1 & 1.3 & 7.2 \\
S2 & 3.8 & 20.4 \\
S3 & 11.9 & 47.9 \\
S4 & 29.5 & 66.5 \\
S5 & 2.9 & 18.3 \\
S6 & 3.2 & 6.6 \\
S7 & 6.2 & 33.6 \\
S8 & 5.6 & 23.9 \\
S9 & 11.6 & 41.5 \\
S10 & 2.6 & 6.7 \\
S11 & 7.8 & 38.5 \\
S12 & 2.3 & 17.2 \\
S13 & 17.0 & 51.7 \\
S14 & 10.6 & 37.8 \\
S15 & 5.2 & 21.2 \\
S16 & 2.8 & 8.6 \\
\hline
\end{tabular}




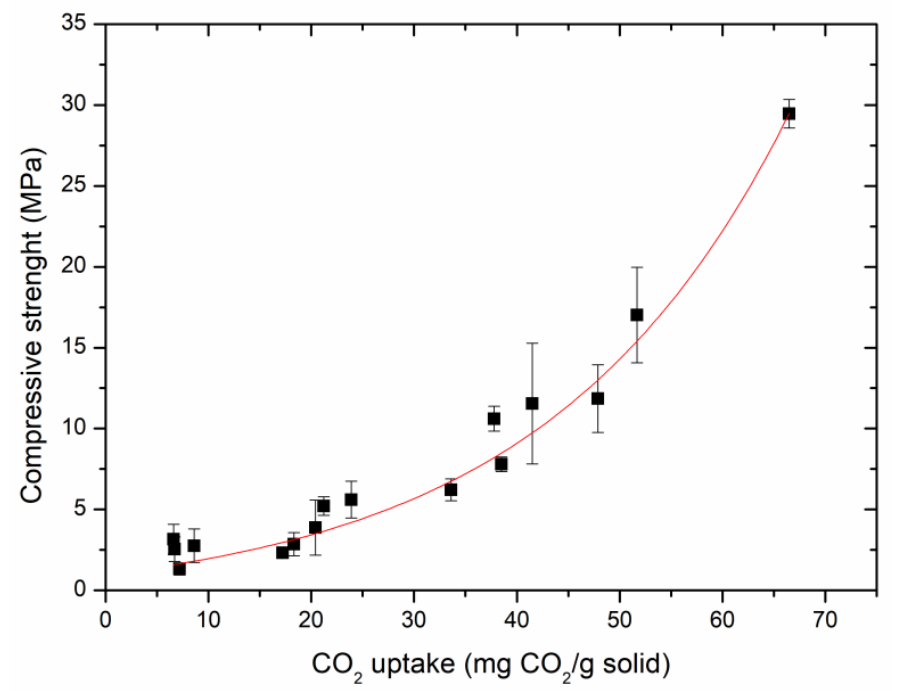

Figure 2. The relationship between compressive strength and $\mathrm{CO}_{2}$ uptake of carbonated tailings-steel slag compacts.

\subsection{Range Analysis}

Range analysis was performed on the orthogonal test results. Table 4 lists the range analysis results of the compressive strength and $\mathrm{CO}_{2}$ uptake capacity of carbonated tailingssteel slag compacts. As shown in Table 4, the optimum scheme with the highest compressive strength is A1B4C4D4 according to the $K$ value. The corresponding reaction conditions are the grinding time of the steel slag at $0 \mathrm{~min}$, the water/solid ratio at 2.5:10, the slag-tailings ratio at 5:5, and the carbonation time at $12 \mathrm{~h}$. The value of the range shows that the degree of the effects of the factors on the compressive strength from high to low is $C>D>A>B$. The effect of the cement-sand ratio (factor $\mathrm{C}$ ) on the compressive strength is the largest, while the water-cement ratio (factor B) has little impact on the compressive strength.

Table 4. Analysis on the range of compressive strength for carbonated tailings-steel slag compacts.

\begin{tabular}{|c|c|c|c|c|c|c|c|c|}
\hline \multirow[t]{2}{*}{ Factors } & \multicolumn{4}{|c|}{ Compressive Strength (MPa) } & \multicolumn{4}{|c|}{$\mathrm{CO}_{2}$ Uptake (mg CO${ }_{2} / g$ Solid) } \\
\hline & A & B & $\mathrm{C}$ & $\mathbf{D}$ & A & B & $\mathrm{C}$ & D \\
\hline K1 & 46.42 & 32.76 & 9.80 & 20.46 & 142.03 & 118.74 & 29.09 & 95.84 \\
\hline $\mathrm{K} 2$ & 17.84 & 20.10 & 14.16 & 34.20 & 82.33 & 71.59 & 77.11 & 134.54 \\
\hline $\mathrm{K} 3$ & 24.20 & 31.06 & 39.62 & 20.02 & 103.95 & 141.13 & 151.19 & 81.49 \\
\hline K4 & 35.60 & 40.14 & 60.48 & 49.38 & 119.30 & 116.16 & 190.22 & 135.74 \\
\hline k1 & 11.61 & 8.19 & 2.45 & 5.12 & 35.51 & 29.69 & 7.27 & 23.96 \\
\hline $\mathrm{k} 2$ & 4.46 & 5.03 & 3.54 & 8.55 & 20.58 & 17.90 & 19.28 & 33.64 \\
\hline k3 & 6.05 & 7.77 & 9.91 & 5.01 & 25.99 & 35.28 & 37.80 & 20.37 \\
\hline k4 & 8.90 & 10.04 & 15.12 & 12.35 & 29.83 & 29.04 & 47.56 & 33.94 \\
\hline Range & 7.15 & 5.01 & 12.67 & 7.23 & 9.52 & 17.39 & 40.28 & 13.56 \\
\hline Ranking & \multicolumn{4}{|c|}{$\mathrm{C}>\mathrm{D}>\mathrm{A}>\mathrm{B}$} & \multicolumn{4}{|c|}{$\mathrm{C}>\mathrm{B}>\mathrm{D}>\mathrm{A}$} \\
\hline Optimum theme & \multicolumn{4}{|c|}{ A1B4C4D4 } & \multicolumn{4}{|c|}{ A1B3C4D4 } \\
\hline
\end{tabular}

Figure $3 a$ shows the effect curves of the four factors on the uniaxial compressive strength of carbonated compacts. As shown in Figure 3a, the influence of the slag-tailings ratio (factor $\mathrm{C}$ ) on the compressive strength is the greatest. With the increase in the slagtailings ratio, the compressive strength of the carbonated compacts shows an increasing trend. However, when the grinding time of the steel slag (factor A) and the water-solid ratio (Factor $\mathrm{B}$ ) increase, the compressive strength of the carbonated compacts initially decrease and then increase. In addition, the effect of the carbonation time (factor D) on the compressive strength of the carbonated compacts fluctuates. 


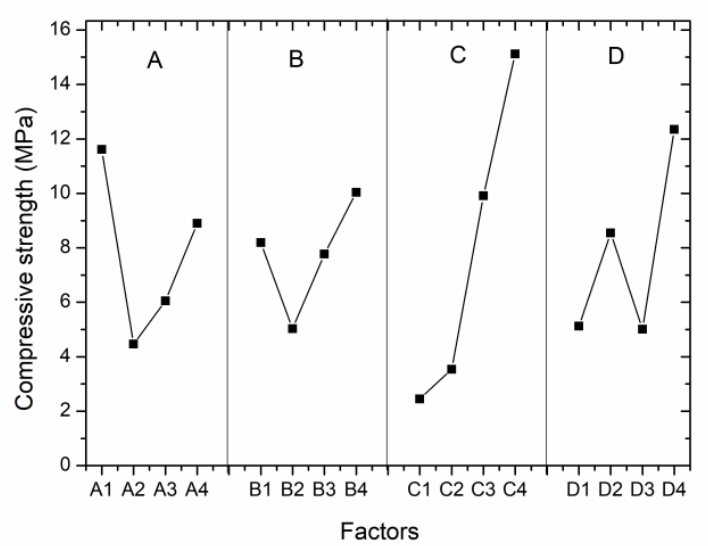

(a)

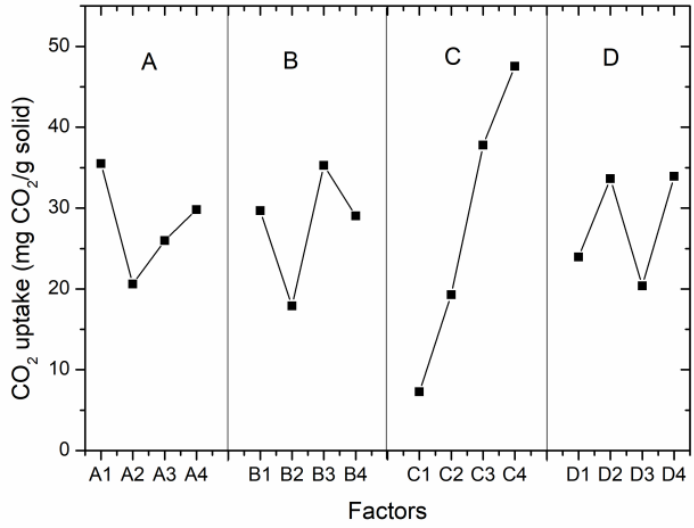

(b)

Figure 3. The effect curve of four factors on (a) compressive strength; (b) $\mathrm{CO}_{2}$ uptake capacity. A is the grinding time for steel slag, B is the water/solid ratio, C is the slag/tailings ratio, D is the carbonation time.

The range analysis results of the $\mathrm{CO}_{2}$ uptake capacity of the orthogonal experiment are presented in Table 4 . Based on the $K$ value, the optimum scheme of the $\mathrm{CO}_{2}$ uptake capacity is A1B3C4D4. The corresponding reaction conditions include steel slag grinding for $0 \mathrm{~min}$, a water/solid ratio of 2:10, a slag/tailings ratio of 5:5, and carbonation for $12 \mathrm{~h}$. From Table 4, the value of the range shows that the degree of the effect of the factors on the $\mathrm{CO}_{2}$ uptake capacity is $\mathrm{C}>\mathrm{B}>\mathrm{D}>\mathrm{A}$. The slag/tailings ratio (factor $\mathrm{C}$ ) plays a substantial role in improving the $\mathrm{CO}_{2}$ uptake capacity, while the grinding time for steel slag (factor $\mathrm{A}$ ) has less influence on the $\mathrm{CO}_{2}$ uptake capacity. The order of the $\mathrm{K}$ value for factor $\mathrm{A}$ is $\mathrm{A}_{1}$, $\mathrm{A}_{4}, \mathrm{~A}_{3}$, and $\mathrm{A}_{2}$.

Figure $3 \mathrm{~b}$ shows the effect curve of four factors on the $\mathrm{CO}_{2}$ uptake capacity of the carbonated compacts. The effects curve of the factors on the $\mathrm{CO}_{2}$ uptake capacity shows a similar trend as that on the compressive strength, except for the water-solid ratio (factor B). With the increase in factor B from 2:10 to 2.5:10, the $\mathrm{CO}_{2}$ uptake capacity decreases, while the compressive strength increases continuously. This indicates that $\mathrm{CO}_{2}$ uptake is not the only reason for material hardening under carbonation curing at $20^{\circ} \mathrm{C}$. The result is in line with Wei et al. [31], who found that hydration also plays an important role during the carbonation curing on steel slag.

\subsection{Direct Analysis}

\subsubsection{The Effect of the Slag/Tailings Ratio on Carbonated Compacts}

Figure 4 shows the $\mathrm{CO}_{2}$ uptake capacity (Figure $4 a$ ) and compressive strength (Figure $4 \mathbf{b}$ ) of each sample grouped by the slag/tailings ratio. The slag/tailings ratio of group C1 is 0 , which means that only ultramafic tailings, without steel slag, were molded and carbonated. In group $\mathrm{C} 1$, the $\mathrm{CO}_{2}$ uptake capacity is in the range of $6.6-8.6 \mathrm{mg} \mathrm{CO} / \mathrm{g}$ solid, and the compressive strength is in the range of 1.33-3.16 MPa. This indicates that ultramafic tailings play a certain role in consolidation during carbonation curing at room temperature. GB50771-2012 (code for design of nonferrous metal mining) stipulates that the compressive strength of filling materials should be no less than $3 \mathrm{MPa}$. The compressive strength of $\mathrm{S} 6$ in group $\mathrm{C} 1$ is $3.16 \mathrm{MPa}$, which meets the requirements for filling materials. Both the $\mathrm{CO}_{2}$ uptake capacity and compressive strength of compacts in group $\mathrm{C} 1$ are generally smaller than those in groups containing steel slag. The carbonation cementation characteristics of ultramafic tailings are worse than those of steel slag under the experimental conditions. This is mainly because the carbonation rate of ultramafic tailings is slower than that of steel slag at room temperature. Thus, steel slag is the main component being carbonated and contributes to the strength development in the steel slag/tailings mixture for carbonation curing at room temperature. 


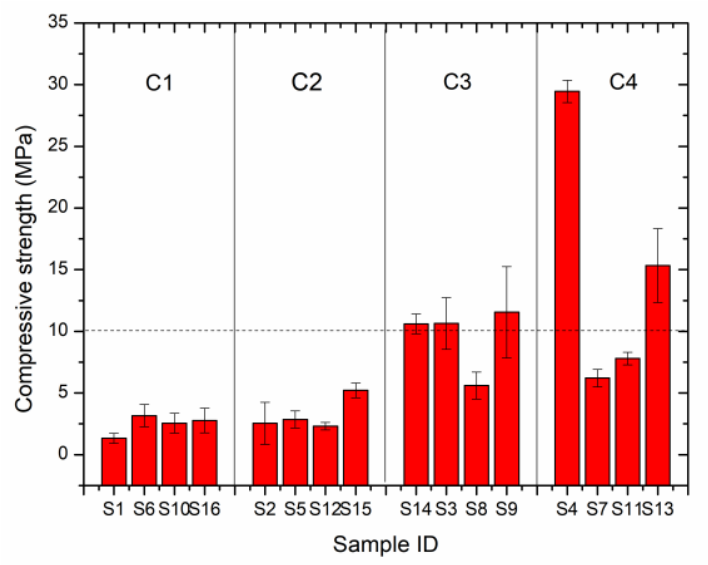

(a)

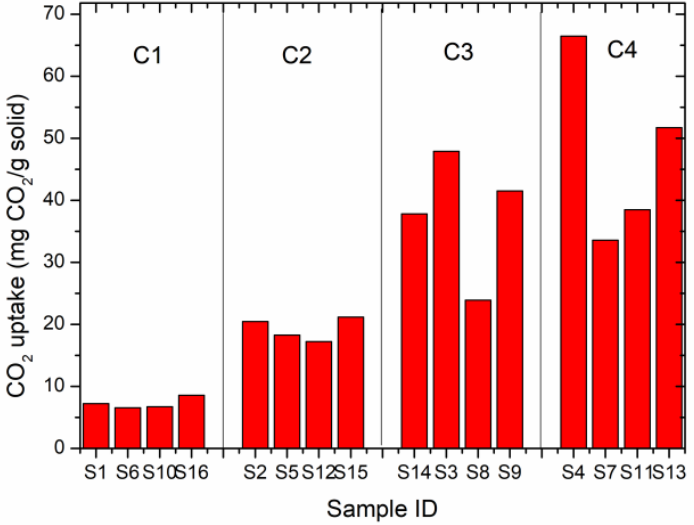

(b)

Figure 4. (a) The compressive strength of compacts grouped by the slag/tailings ratio; (b) The $\mathrm{CO}_{2}$ uptake capacity of compacts grouped by the slag-tailings ratio. The slag/tailings ratios of C1, C2, C3, C4 are $0,1: 9,3: 7$ and 5:5, respectively.

The slag-tailings ratio of group $\mathrm{C} 2$ is $1: 9$. Figure 4 shows that the $\mathrm{CO}_{2}$ uptake capacity of group $\mathrm{C} 2$ is in the range of $18.3-21.2 \mathrm{mg} \mathrm{CO}_{2} / \mathrm{g}$ solid, and the compressive strength of group $\mathrm{C} 2$ is in the range of $2.31-5.21 \mathrm{MPa}$. The $\mathrm{CO}_{2}$ uptake capacity of group $\mathrm{C} 2$ is two to three times that of group $\mathrm{C} 1$. However, the compressive strength of group C2 is only 1-1.5 times that of group C1. It can be seen that $10 \%$ steel slag in the mixture is far from enough to improve the mechanical properties of carbonated compacts, and effective carbonation cementation has not yet been achieved.

The slag-tailings ratio of group $\mathrm{C} 3$ is 3:7. Figure 4 shows that the $\mathrm{CO}_{2}$ uptake capacity of group $\mathrm{C} 3$ is in the range of $23.9-47.9 \mathrm{mg} \mathrm{CO}_{2} / \mathrm{g}$ solid, and the compressive strength of group C3 is in the range of 5.6-11.85 MPa. Except for S8, the compressive strengths of the samples in group C3 are all over $10 \mathrm{MPa}$, which are higher than the molding pressure $(9 \mathrm{MPa})$. This indicates that to achieve effective cementation in a carbonation curing process at room temperature, at least 30\% steel slag is required in the mixture prepared for carbonated building material. The slag/tailings ratio of 3:7 is similar to the adoptable binder/aggregates ratio of concrete [47].

The slag/tailings ratio of group $\mathrm{C} 4$ is 5:5. Figure 4 shows that the $\mathrm{CO}_{2}$ uptake capacity of group $\mathrm{C} 4$ is in the range of $30.5-66.5 \mathrm{mg} \mathrm{CO} / \mathrm{g}$ solid, and the compressive strength of group C4 is in the range of 6.21-29.46 MPa. The compressive strength of S4 meets the requirements of MU25 brick according to JC/T422-2007 (non-fired rubbish gangue brick). The mixture containing 50\% steel slag is supposed to have higher cementation effects than mixtures containing 30\% steel slag after carbonation. However, the compressive strengths of S7 and S11 are even lower than $10 \mathrm{MPa}$. It is necessary to adopt an appropriate grinding time for steel slag, water solid ratio, and carbonation time to produce a carbonated steel slag/tailings material with a high compressive strength.

\subsubsection{The Effect of the Water-Solid Ratio on Carbonated Compacts}

Water plays an important role during the carbonation curing of steel slag. It is the raw material in steel slag hydration, as well as the catalysis of steel slag carbonation. According to Table 4, the degree of the effect of the water-solid ratio on the $\mathrm{CO}_{2}$ uptake capacity ranks second, while the degree of the effect of the water-solid ratio on the compressive strength is the last among the four selected factors. This indicates that the strength of carbonated compacts is not only determined by the carbonation reaction. The results are consistent with those of Wang et al. [15], who believes that carbonation and hydration of steel slag compete and promote each other during the carbonation curing process. 
As shown in Figure 3, with the increase in the water-solid ratio, the $\mathrm{CO}_{2}$ uptake capacity and compressive strength of carbonated compacts changed in different ways. When the water-solid ratio increased from 2:10 to 2.5:10, the $\mathrm{CO}_{2}$ uptake capacity decreased, while the compressive strength continuously increased. During the molding process, a small amount of water was pressed out in the samples with a water-solid ratio of 2.5:10. Excessive water may hinder the carbonation rate of steel slag. The results are consistent with Humbert et al. [32], who found that excessive water aggregated and accumulated to wrap the steel slag surface, which is not preferred to the carbonation reaction.

\subsubsection{The Effect of the Carbonation Time on Carbonated Compacts}

S12 (A3B4C2D1), S8 (A2B4C3D2), and S4 (A1B4C4D4) were prepared with a watersolid ratio of 2.5:10, which is the highest value used in the experiments. As shown in Figure 4, the $\mathrm{CO}_{2}$ uptake capacity and compressive strength of S12 and S8 are the lowest in groups $\mathrm{C} 2$ and $\mathrm{C} 3$, respectively, while the counterparts of $\mathrm{S} 4$ are the highest in group C4. The differences among S12, S8, and S4 are the carbonation curing times, which are 1, 3 , and $12 \mathrm{~h}$, respectively. The result is in line with Wang et al. [44], who found that the enhances in $\mathrm{CO}_{2}$ uptake and compressive strength of steel slag compacts with the increase of carbonation time.

It seems that a high water-solid ratio inhibits early carbonation, but promotes longterm carbonation. On the one hand, excessive water is continuously consumed due to hydration or evaporation during carbonation curing and is no longer capable of hindering carbonation with increasing carbonation curing time. On the other hand, steel slag needs a long duration to react with water due to its slow hydration rate. The result is consistent with Wei et al. [31], who found that long-term carbonation could benefit from the hydration of steel slag by producing a large amount of C-S-H gel as a carbonation precursor (reaction 2).

\subsubsection{The Effect of the Grinding Time for Steel Slag on Carbonated Compacts}

As seen from Table 4, among the four factors, steel slag grinding time has the least degree of effect on the $\mathrm{CO}_{2}$ uptake capacity and compressive strength of the carbonated compacts. As shown in Figure 3, with the increase in grinding time, the $\mathrm{CO}_{2}$ uptake capacity and compressive strength of carbonated compacts first decreased and then increased. This is inconsistent with the results of Wang et al. [48], who found that with increasing fines, the hydration activity of steel slag increased, and the strength of steel slag concrete also increased. The differences are mainly due to the variation of consolidation mechanism of hydration and carbonation. Carbonation curing on the steel slag compact experiences the diffusion of $\mathrm{CO}_{2}$ from the surface to the core [15]. Thus, the high compressive strength and $\mathrm{CO}_{2}$ uptake of non-ground steel slag compacts after carbonation curing may be due to the high permeability, which promote $\mathrm{CO}_{2}$ migration into the core of the compacts.

Figure 5 shows the $\mathrm{CO}_{2}$ uptake capacity and compressive strength of carbonated compacts grouped by grinding time for steel slag. As shown in Figure 5, the large value of group A1 in the experimental group may be due to the design of the orthogonal experiment. S3 (A1B3C3D3) and S4 (A1B4C4D4) in group A1 not only have a long grinding time for steel slag, but also have a large slag-tailings ratio, which leads to the average $\mathrm{CO}_{2}$ uptake capacity and average compressive strength of group A1 being the highest among all groups. Also, the optimum mix may not have been one of the ones prepared, for example A4B4C4D4. It seems that the optimum condition is selected as one of those prepared in this work, and not the absolute optimum that should be validated. Orthogonal tests can effectively and quickly identify priority control factors; however, they have some inherent limitations in analyzing the effect of each factor on the objective results. Advanced techniques (i.e., single factor test analysis, response surface analysis, and nonlinear regression model) are needed to accurately analyze the mechanism of each factor on the $\mathrm{CO}_{2}$ uptake capacity and compressive strength. 


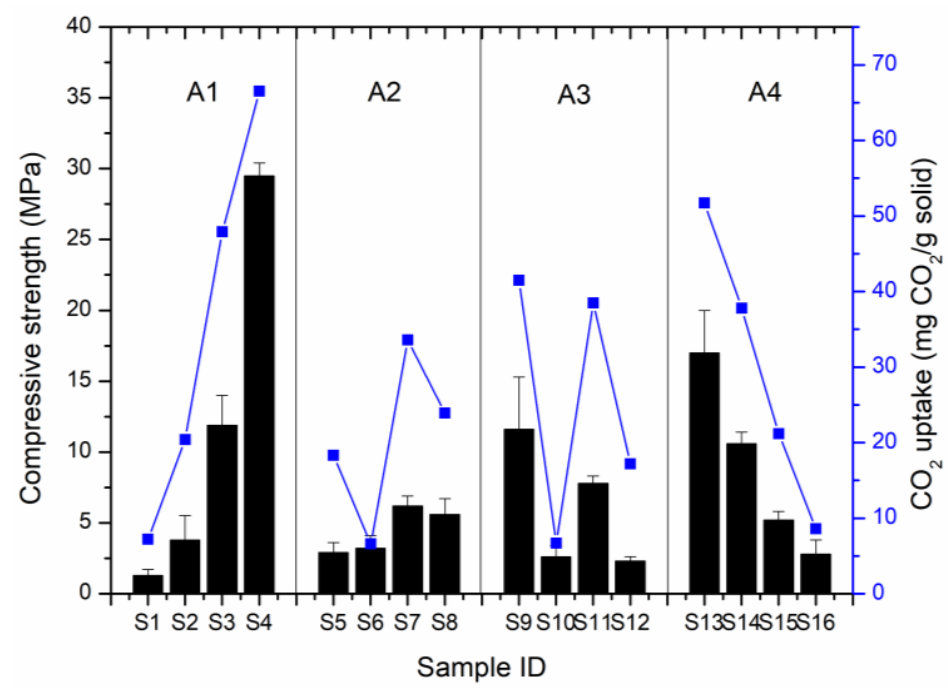

Figure 5. $\mathrm{CO}_{2}$ uptake and compressive strength of samples grouped by the grinding time of steel slag. The black bars show the values of compressive strength. The blue lines display the values of $\mathrm{CO}_{2}$ uptake. The grinding time for steel slag of $\mathrm{A} 1, \mathrm{~A} 2, \mathrm{~A} 3, \mathrm{~A} 4$ are 0, 30, 60 and 120 min, respectively.

\subsection{Microstructure Analysis on the Optimal Samples}

\subsubsection{X-ray Diffraction Analysis}

The results in Table 4 indicate that the compressive strength and $\mathrm{CO}_{2}$ uptake capacity of S4 are the best, and the combination is A1B4C4D4. The optimized levels of the comprehensive strength and $\mathrm{CO}_{2}$ uptake capacity in the results of the analysis are A1B4C4D4 and A1B3C4D4, respectively. Since the compressive strength is more important than the $\mathrm{CO}_{2}$ uptake for a carbonated building material, A1B4C4D4 (S4) was chosen as the optimal sample.

The line profile analysis of the XRD patterns qualitatively and semi-quantitatively characterizes the crystalline part of a sample. Figure 6 shows the XRD patterns of ultramafic tailings, steel slag, and S4. The main mineral in ultramafic tailings is serpentine $\left(\mathrm{Mg}_{3}\left(\mathrm{Si}_{2} \mathrm{O}_{5}\right)(\mathrm{OH})_{4}\right)$. The main minerals in steel slag are larnite $\left(\mathrm{C}_{2} \mathrm{~S}\right)$, hatrurite $\left(\mathrm{C}_{3} \mathrm{~S}\right)$, srebrodolskite $\left(\mathrm{C}_{2} \mathrm{~F}\right)$, mayenite $\left(\mathrm{C}_{12} \mathrm{~A}_{7}\right)$, portlandite $\left(\mathrm{Ca}(\mathrm{OH})_{2}\right)$, and $\mathrm{RO}$ phase $(\mathrm{FeO}, \mathrm{MgO}$, $\mathrm{MnO})$. $\mathrm{S} 4$ contains nearly all phases that appear in both the steel slag and tailings and a new calcite $\left(\mathrm{CaCO}_{3}\right)$ phase. This indicates that calcite is formed during carbonation curing on the mixture of steel slag and tailings.

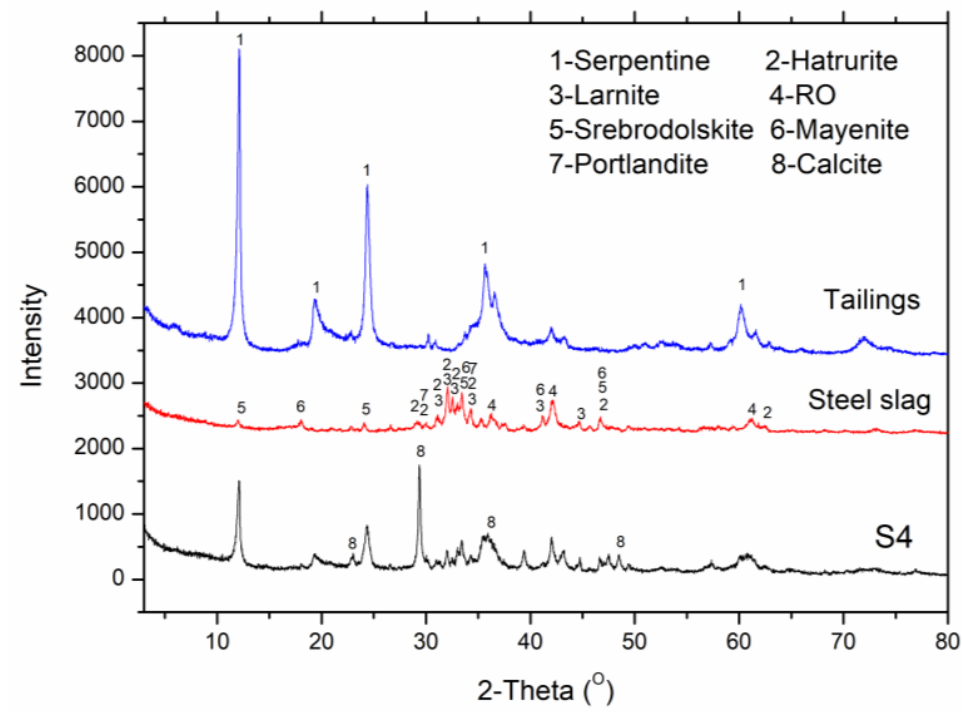

Figure 6. X-ray diffraction pattern of ultramafic tailings, steel slag, and S4. 
Table 5 lists the mineral composition of the steel slag, ultramafic tailings, mixture with slag/tailings ratio of 5:5, and S4. The mineral composition of the mixture is calculated according to that of steel slag and ultramafic tailings, with the assumption that both steel slag and tailings are not altered during the compact preparation processes. Table 5 shows that $\mathrm{C}_{2} \mathrm{~S}, \mathrm{C}_{3} \mathrm{~S}, \mathrm{Ca}(\mathrm{OH})_{2}$ and $\mathrm{C}_{12} \mathrm{~A}_{7}$ dramatically consumed. The carbonation conversion of each phase ranged from 83 to $100 \%$ after $12 \mathrm{~h}$ carbonation. The result is in consist with Wang et al. [15] who found that the carbonation and hydration of those minerals contributes the strength development of the whole system.

Table 5. The mineral composition of ultramafic tailings, steel slag, and S4.

\begin{tabular}{|c|c|c|c|c|}
\hline Phases & Steel Slag & Ultramafic Tailings & Mixture $(S: T=1: 1)^{a}$ & S4 \\
\hline larnite $\left(\mathrm{C}_{2} \mathrm{~S}\right)$ & $36.7 \%$ & & $18.4 \%$ & $2.8 \%$ \\
\hline hatrurite $\left(C_{3} S\right)$ & $11.9 \%$ & & $6.0 \%$ & $0.1 \%$ \\
\hline portlandite $\left(\mathrm{Ca}(\mathrm{OH})_{2}\right)$ & $12.5 \%$ & & $6.3 \%$ & $0.0 \%$ \\
\hline mayenite $\left(\mathrm{C}_{12} \mathrm{~A}_{7}\right)$ & $4.8 \%$ & & $2.4 \%$ & $0.5 \%$ \\
\hline srebrodolskite $\left(\mathrm{C}_{2} \mathrm{~F}\right)$ & $17.6 \%$ & & $8.8 \%$ & $9.8 \%$ \\
\hline $\mathrm{RO}(\mathrm{FeO}, \mathrm{MgO}, \mathrm{MnO})$ & $15.0 \%$ & $7.7 \%$ & $11.4 \%$ & $10 \%$ \\
\hline calcite $\left(\mathrm{CaCO}_{3}\right)$ & $0.6 \%$ & & $0.3 \%$ & $23.6 \%$ \\
\hline lizardite & & $92.3 \%$ & $46.2 \%$ & $53.3 \%$ \\
\hline
\end{tabular}

Note: ${ }^{\mathrm{a}}$. is calculated according to the mineral composition of steel slag and ultramafic tailings.

The weight percentage of iron containing phases $\left(\mathrm{C}_{2} \mathrm{~F}\right.$ and $\left.\mathrm{RO}\right)$ in the mixture and S4 are 20.1 and $19.8 \%$, respectively. The changes in the weight percentage of $\mathrm{C}_{2} \mathrm{~F}$ and $\mathrm{RO}$ are less than $5 \%$ after carbonation curing, which could recognize as unchanged since the calculation error of $\mathrm{XRD}$ is $5 \%$. It indicates that Fe containing minerals are very resistant to $\mathrm{CO}_{2}$ when curing at room temperature. The $\mathrm{RO}$ phase in steel slag was also found inert in the hydration system, Wang et al. [48]. Magnetite separation prior to carbonation curing could potentially improve the cremations behavior of steel slag. Increasing the carbonation curing temperature would be another strategy to enhance the carbonation rate of $\mathrm{RO}$ [49].

Table 5 shows an increase in lizardite after carbonation curing. It may be due to the formation of amorphous phases (i.e., C-S-H gel, silica gel), which were assumed to be the lizardite structure. An overestimation of lizardite by XRD analysis was also found in the carbonated ultramafic tailings [50].

No magnesium carbonates phases were found in the D4, which indicates that the carbonation of ultramafic tailings is too slow under room temperature. The result is not in line with Harrison et al. [51], who observed $\mathrm{MgCO}_{3} 3 \mathrm{H}_{2} \mathrm{O}$ in the carbonated ultramafic tailings. This is due to absence of $\mathrm{Mg}(\mathrm{OH})_{2}$ in the ultramafic tailings of this study. Pretreatment (i.e., heat treatment and chemical treatment) of ultramafic tailings is necessary to enhance its carbonation activity, which may promote the carbonation consolidation behavior of ultramafic tailings.

\subsubsection{Thermal Analysis}

Figure 7 shows the results of TG-DTA analysis on the steel slag, ultramafic tailings, and S4. Table 6 lists the weight loss of the samples at different temperature intervals. The evaporation of interlayer water occurred below $145^{\circ} \mathrm{C}$, the dihydroxylation of C-S-H gel occurred between 145 and $330^{\circ} \mathrm{C}$, and the loss of $\mathrm{Ca}(\mathrm{OH})_{2}$ occurred between 330 and $500{ }^{\circ} \mathrm{C}$ [28]. 


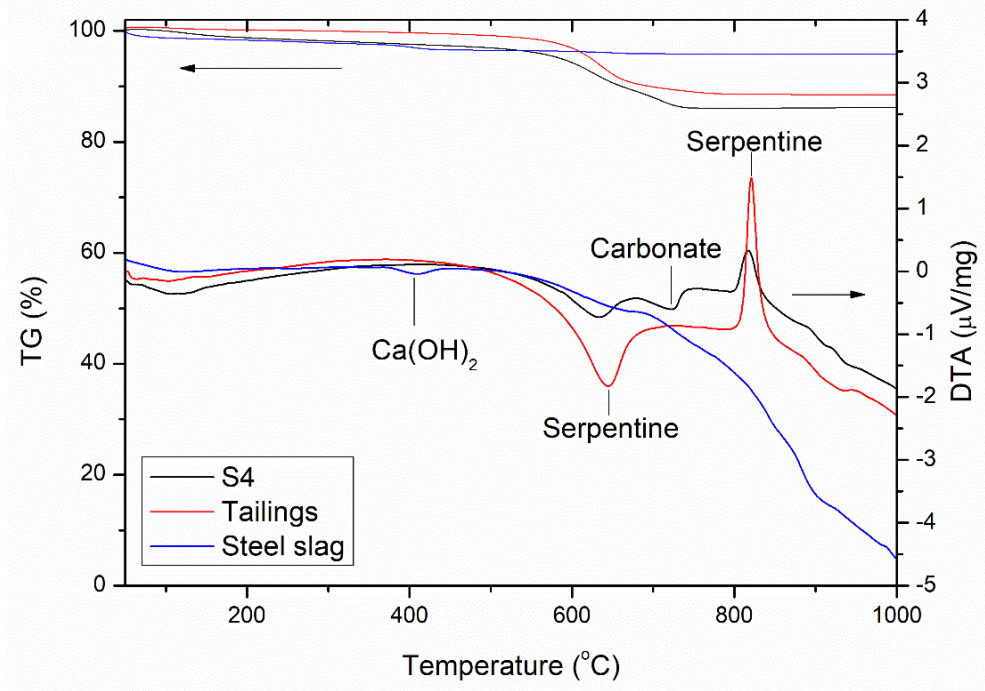

Figure 7. TG-DTA curve of ultramafic tailings, steel slag, and S4.

Table 6. The weight loss of samples at different temperature intervals (wt $\%)$.

\begin{tabular}{ccccccc}
\hline & $\mathbf{5 0 - 1 4 5}{ }^{\circ} \mathbf{C}$ & $\mathbf{1 4 5 - 3 3 0}{ }^{\circ} \mathbf{C}$ & $\mathbf{3 3 0 - 5 0 0}{ }^{\circ} \mathbf{C}$ & $\mathbf{5 0 0 - 8 0 0}{ }^{\circ} \mathbf{C}$ & $\mathbf{8 0 0 - 1 0 0 0}{ }^{\circ} \mathbf{C}$ & $\mathbf{L O I}$ \\
\hline Tailings & - & 0.1 & 0.8 & 10.5 & 0.1 & 11.5 \\
Steel slag & 1.4 & 0.9 & 1.2 & 0.7 & 0.1 & 4.3 \\
Mixture & 0.7 & 0.5 & 1.0 & 5.6 & 0.1 & 7.9 \\
$(\mathrm{~S}: \mathrm{T}=1: 1)$ a & 0.7 & 1.3 & 1.1 & 10.9 & -0.1 & 13.9 \\
S4 & 0.7 &
\end{tabular}

Table 6 shows that ultramafic tailings have very limited weight loss below $500{ }^{\circ} \mathrm{C}$. Figure 7 shows that there is a remarkable weight loss and a sharp exothermic DTA signal in ultramafic tailings, corresponding to serpentine dihydroxylation $\left(642^{\circ} \mathrm{C}\right)$ [52] and forsterite formation $\left(819{ }^{\circ} \mathrm{C}\right)$ [53], respectively. The total weight loss up to $1000{ }^{\circ} \mathrm{C}$ is $11.5 \%$ for ultramafic tailings, which is in agreement with the result for the theoretical chemicalbonded water of serpentine [52]. The TG-DTA results of ultramafic tailings are in line with their XRD results.

Table 6 shows that the weight loss of steel slag below $500{ }^{\circ} \mathrm{C}$ is $3.5 \%$, which takes up to $83.3 \%$ of the total weight loss up to $1000{ }^{\circ} \mathrm{C}$. Figure 7 shows that there is a mass loss step in the steel slag, which is $\mathrm{Ca}(\mathrm{OH})_{2}$ (approximately $400{ }^{\circ} \mathrm{C}$ ) [28]. The existing of $\mathrm{Ca}(\mathrm{OH})_{2}$ in steel slag make the building materials containing steel slag have a poor soundness [54]. Although the weight loss of $\mathrm{S} 4$ between $330-500{ }^{\circ} \mathrm{C}$ is similar to that of steel slag (Table 6), no dihydroxylation of $\mathrm{Ca}(\mathrm{OH})_{2}$ appears in the DTA curve of S4 (Figure 5). It indicates that $\mathrm{CO}_{2}$ could neutralize $\mathrm{Ca}(\mathrm{OH})_{2}$ and stabilize the volume of building materials containing steel slag. The result is in line with Wang et al. [34], who found that the durability of carbonated steel slag compacts was higher than hydrated ones, when they were placed in a hydration environment for a year.

The weight losses of $\mathrm{S} 4$ in the range of $145-330^{\circ} \mathrm{C}$ and $500-800{ }^{\circ} \mathrm{C}$ are nearly twice the value of the mixture. This indicates the formation of C-S- $\mathrm{H}$ gel and $\mathrm{CaCO}_{3}$ during carbonation curing. A similar result was found by Wang et al. [15], who addressed that both carbonation and hydration took place when carbonation curing of steel slag at room temperature.

There is a double weight loss step between 500 and $800{ }^{\circ} \mathrm{C}$ (Figure 7), corresponding to the decomposition of serpentine (approximately $633^{\circ} \mathrm{C}$ ) and calcite (approximately $\left.722{ }^{\circ} \mathrm{C}\right)$ [28]. This indicates that serpentine still exist and calcite was formed after carbonation curing at room temperature, which is in line with the XRD results. 


\subsubsection{Morphology and Chemical Analysis}

SEM-EDS tests were carried out to characterize the morphology and chemical composition of the samples. Figure 8 shows the morphology of steel slag before mechanical activation, ultramafic tailings, and S4. As shown in Figure 8a, ultramafic tailings contain lizardite fragments of various sizes and long chrysotile fibers. It is in line with XRD and TG-DTA results. Figure $8 \mathrm{~b}$ shows that the steel slag contains some large particles $(\sim 10 \mu \mathrm{m})$ with sharp angles, many nanosized particles, and some aggregates of nanosized particles. The steel slag was ground for $30 \mathrm{~min}$ for sample preparation. The large particles indicate that some minerals (i.e., $\mathrm{C}_{2} \mathrm{~S}$ ) in steel slag are very resistant to grinding.

Figure $8 \mathrm{c}$,d show that various particles bond together in S4. As shown in Figure 8c, the gap of the sample is filled with many $1-\mu \mathrm{m}$ hexagonal particles. The EDS results indicate that most of the elements of the hexagonal particles are $\mathrm{C}, \mathrm{O}$, and $\mathrm{Ca}$. The SEM-EDS results are in line with the XRD and TGA results, which found that the newly generated phase of carbonated materials is $\mathrm{CaCO}_{3}$. The hexagonal shape of $\mathrm{CaCO}_{3}$ indicates that the main carbonation product is calcite. It can be concluded that the hardening of tailings and steel slag mixtures after carbonation curing is due to the formation of micrometer-sized calcite, which is compactly arranged in the gap among the particles and binds the particles together. The findings are consistent with the results of Wang et al. [34], who studied the carbonation curing of steel slag compacts.

As shown in Figure 8d, fibrous chrysotile also appears in the compact and physically links the particles. The addition of mineral fibers into concrete is a poriferous strategy to enhance the flexural strength, flexural toughness, and fracture energy of high-performance concrete [55]. Even though the carbonation cementitious activity of serpentine is much lower than that of steel slag at $20^{\circ} \mathrm{C}$, serpentine could contribute to the mechanical properties of the mixture compact through other ways, such as by its fibrous structure.

Although the potential usage of the carbonated compacts were suggested according to their compressive strength, their environmental feasibility and durability cannot be omitted. Further studies will focus on the environmental properties (i.e., leachability, $\mathrm{pH}$, and heavy metals leaching) of carbonated compacts, as well as their strength development when subject to special conditions (i.e., freezing and thawing, ion corrosion).

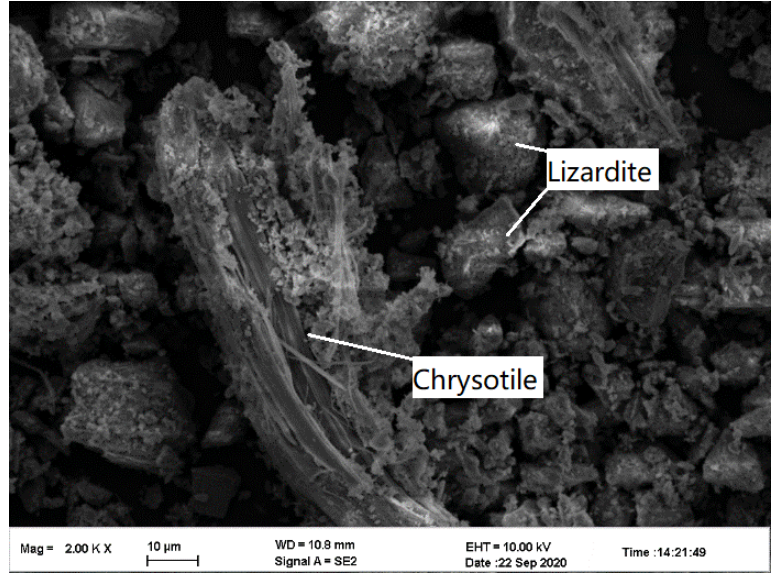

(a)

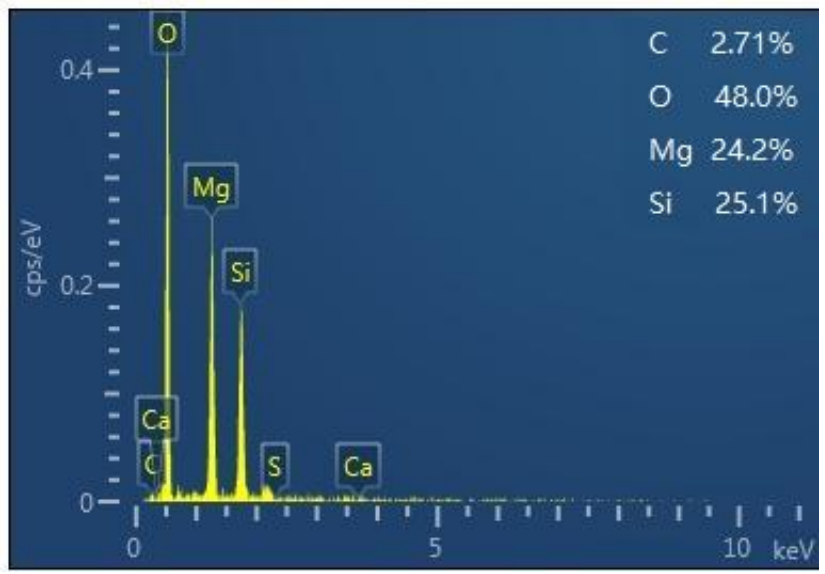

(a1)

Figure 8. Cont. 


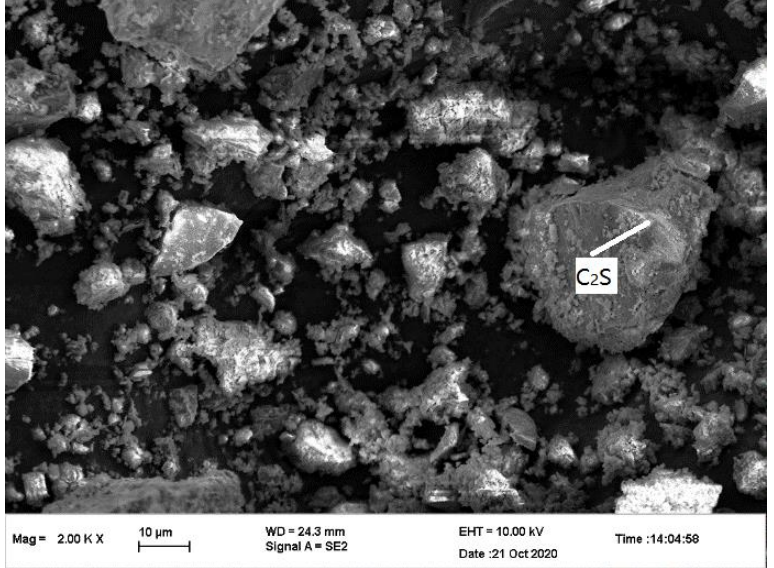

(b)

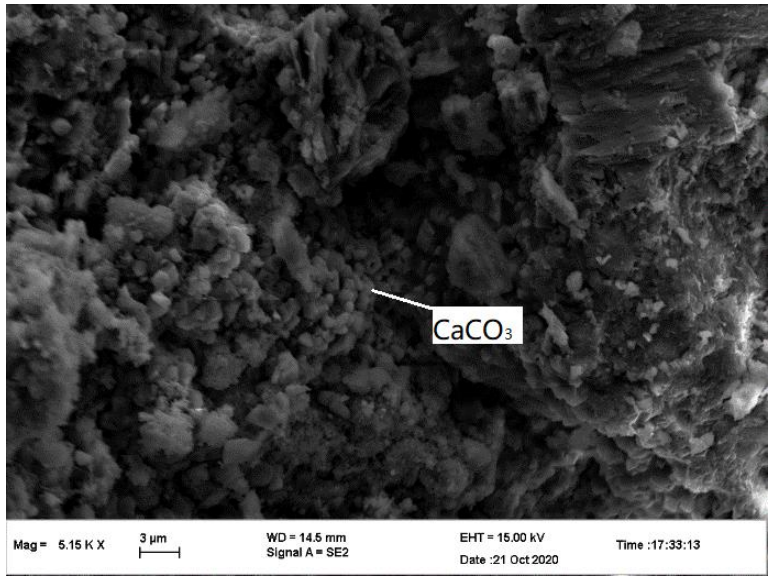

(c)

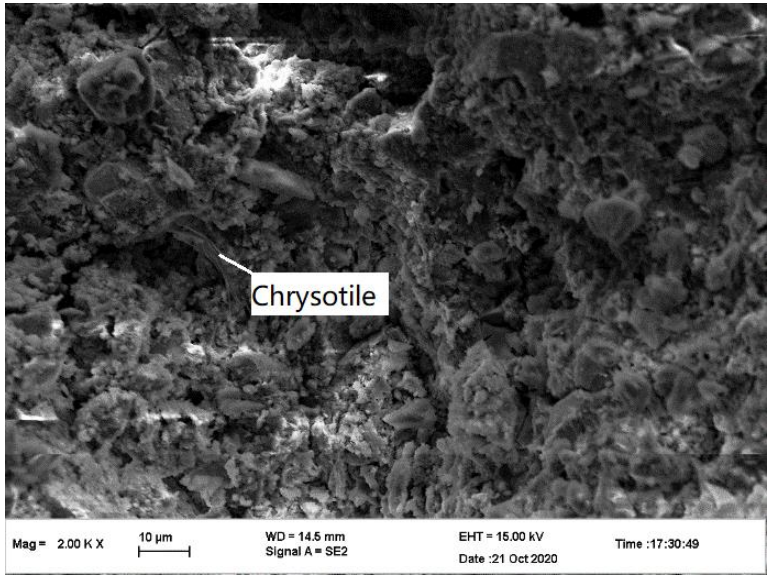

(d)

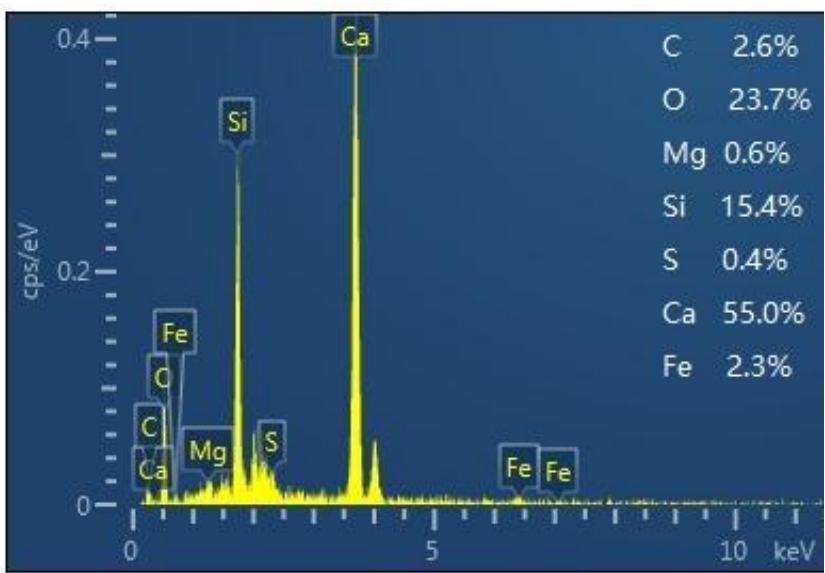

(b1)

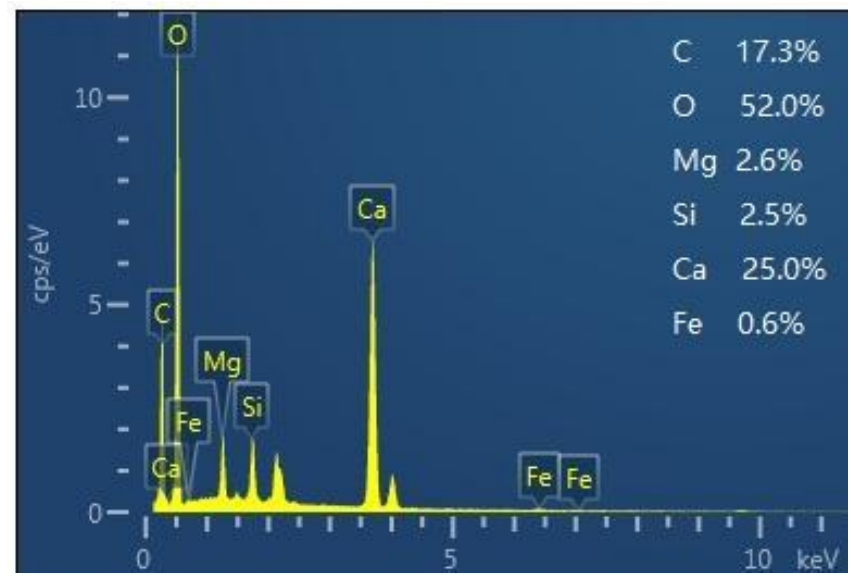

(c1)

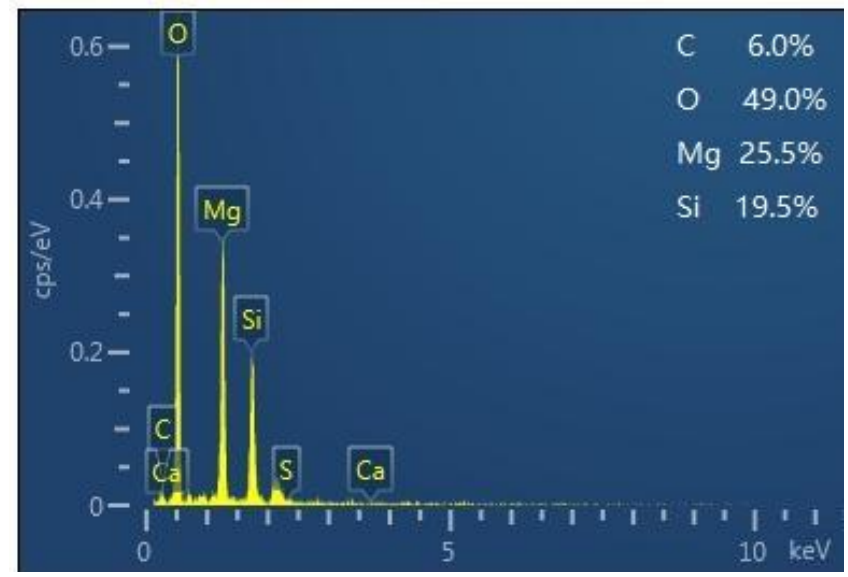

(d1)

Figure 8. The micrograph and EDS spectra of samples. (a) The micrograph of ultramafic tailings; (b) The micrograph of steel slag; (c,d)The micrograph of S4; (a1) The EDS spectra of chrysotile on (a); (b1) The EDS spectra of $\mathrm{C}_{2} \mathrm{~S}$ on (b); (c1) The EDS spectra of $\mathrm{CaCO}_{3}$ on (c); (d1) The EDS spectra on Chrysotile on (d). The scale bar in (a,b,d) are $10 \mu \mathrm{m}$ and in (c) is $3 \mu \mathrm{m}$.

\section{Conclusions}

This study examines the effect of carbonation curing on steel slag with ultramafic tailings as fine aggregates through orthogonal tests. This provides guidance for the development of carbonated concrete for CCUS. The key findings are summarized as follows: 
(1) The compressive strength is positively exponentially related to the $\mathrm{CO}_{2}$ uptake capacity in the carbonated tailings-steel slag compacts. The optimal reaction conditions are steel slag grinding for $0 \mathrm{~min}$, a water/solid ratio of 2.5:10, a slag/tailings ratio of 5:5, and carbonation curing for $12 \mathrm{~h}$. The compressive strength of the carbonated compact reaches $29 \mathrm{MPa}$ under the optimal reaction conditions.

(2) The range analysis results of the orthogonal test show that the degree of the effects on the compressive strength of carbonated tailings-steel slag compacts ordered from large to small is slag-tailings ratio $>$ carbonation time $>$ grinding time for steel slag $>$ water-solid ratio. The degree of the effects on the $\mathrm{CO}_{2}$ uptake capacity of carbonated tailings-steel slag compacts ordered from large to small is slag-tailings ratio $>$ water-solid ratio $>$ carbonation time $>$ grinding time for steel slag.

(3) A high water-solid ratio hinders the early carbonation reaction (1-3 h) and early strength development, but promotes the long-term $(12 \mathrm{~h})$ carbonation reaction and long-term strength development of carbonated tailings-steel slag compacts.

(4) Steel slag are the main component for the hardening of carbonated tailings-steel slag compacts, while the fibrous minerals in the ultramafic tailings enforces the strength of the compacts.

Author Contributions: Conceptualization, J.L. and C.W.; Methodology, J.L.; Validation, W.N., S.Z. and F.J.; Formal analysis, J.L. and C.W.; Investigation, J.L. and C.W.; Resources, W.N.; Data curation, B.H. and S.M.; Writing—original draft preparation, J.L. and C.W.; Writing—review and editing, S.M. and M.H.; Supervision, W.N., F.J., H.Z. and X.S.; Project administration, J.L.; Funding acquisition, J.L., S.Z. and W.N. All authors have read and agreed to the published version of the manuscript.

Funding: This research was funded by National Key R\&D Program of China, grant number 2018YFC1900603; National Natural Science Foundation of China, grant number 52004021 and 51904017; Fundamental Research Funds for the Central Universities and the Youth Teacher International Exchange \& Growth Program, grant number QNXM20210006; The State Key Laboratory of Coal Resources and Safe Mining, CUMT, grant number SKLCRSM19KF007; Major Project of Scientific and Technological Innovation of Shandong, grant number 2019SDZY02; and 111 Project, grant number B20041.

Acknowledgments: We thank Mei Zhang and Shouliang Ni for the analytical assistance.

Conflicts of Interest: The authors declare no conflict of interest.

\section{References}

1. IPCC. IPCC Special REPORT on Climate Change, Desertification, Land Degradation, Sustainable Land Management, Food Security, and Greenhouse Gas Fluxes in Terrestrial Ecosystems; Shukla, P.R., Skea, J., Calvo Buendia, E., Masson-Delmotte, V., Pörtner, H.-O., Roberts, D.C., Zhai, P., Slade, R., Connors, S., van Diemen, R., et al., Eds.; 2019, in press. Available online: https: //www.ipcc.ch/site/assets/uploads/sites/4/2021/07/210714-IPCCJ7230-SRCCL-Complete-BOOK-HRES.pdf (accessed on 10 February 2022).

2. GOSAT. The Whole-Atmosphere Monthly Mean $\mathrm{CO}_{2}$ Concentration Based on GOSTA Observation. Available online: http: / / www.gosat.nies.go.jp/en/recent-global-co2.html (accessed on 15 February 2020).

3. NOAA National Centers for Environmental Information. State of the Climate: Global Climate Report for 2021. Available online: https://www.ncdc.noaa.gov/sotc/global/202113/supplemental/page-1 (accessed on 15 February 2020).

4. UNFCCC. Paris Agreement. Unitted Nations. 2015. Available online: https://unfccc.int/sites/default/files/english_paris_ agreement.pdf (accessed on 15 February 2020).

5. Tu, Z.; Guo, M.Z.; Poon, C.S.; Shi, C. Effects of limestone powder on $\mathrm{CaCO}_{3}$ precipitation in $\mathrm{CO}_{2}$ cured cement pastes. Cem. Concr. Compos. 2016, 72, 9-16. [CrossRef]

6. Lord, M. Rethinking Cement; Beyound Zero Emissions Inc.: Victoria, Austrilia, 2017; Available online: https://bze.org.au/wpcontent/uploads/2020/12/rethinking-cement-bze-report-2017.pdf (accessed on 15 February 2020).

7. Huang, X.; Wang, Z.; Liu, Y.; Hu, W.; Ni, W. On the use of blast furnace slag and steel slag in the preparation of green artificial reef concrete. Costr. Build. Mater. 2016, 112, 241-246. [CrossRef]

8. Lippiatt, N.; Ling, T.C.; Pan, S.Y. Towards carbon-neutral construction materials: Carbonation of cement-based materials and the future perspective. J. Build. Eng. 2020, 28, 101062. [CrossRef]

9. Ashraf, W. Carbonation of cement-based materials: Challenges and opportunities. Constr. Build. Mater. 2016, 120, 558-570. [CrossRef] 
10. Younsi, A.; Turcry, P.; Rozire, E.; Ait-Mokhtar, A.; Loukili, A. Performance-based design and carbonation of concrete with high fly ash content. Cem. Concr. Compos. 2011, 33, 993-1000. [CrossRef]

11. Liang, C.; Pan, B.; Ma, Z.; He, Z.; Duan, Z. Utilization of $\mathrm{CO}_{2}$ curing to enhance the properties of recycled aggregate and prepared concrete: A review. Cem. Concr. Compos. 2020, 105, 103446. [CrossRef]

12. Qiu, Q. A state-of-the-art review on the carbonation process in cementitious materials: Fundamentals and characterization techniques. Constr. Build. Mater. 2020, 247, 118503. [CrossRef]

13. Zhang, D.; Ghouleh, Z.; Shao, Y. Review on carbonation curing of cement-based materials. J. CO 2 Util. 2017, $21,119-131$. [CrossRef]

14. Liu, Z.; Meng, W. Fundamental understanding of carbonation curing and durability of carbonation-cured cement-based composites: A review. J. $\mathrm{CO}_{2}$ Util. 2021, 44, 101428. [CrossRef]

15. Wang, X.; Ni, W.; Li, J.; Zhang, S.; Hitch, M.; Pascual, R. Carbonation of steel slag and gypsum for building materials and associated reaction mechanisms. Cem. Concr. Res. 2019, 125, 105893. [CrossRef]

16. Librandi, P.; Nielsen, P.; Costa, G.; Snellings, R.; Quaghebeur, M.; Baciocchi, R. Mechanical and environmental properties of carbonated steel slag compacts as a function of mineralogy and $\mathrm{CO}_{2}$ uptake. J. $\mathrm{CO}_{2}$ Util. 2019, 33, 201-214. [CrossRef]

17. Das, B.; Prakash, S.; Reddy, P.S.R.; Misra, V.N. An overview of utilization of slag and sludge from steel industries. Resour. Conserv. Recycl. 2007, 50, 40-57. [CrossRef]

18. World Steel Association. Global Crude Steel Output Increases by 3.4\% in 2019. Available online: https://worldsteel.org/mediacentre/press-releases/2020/global-crude-steel-output-increases-by-3-4-in-2019/ (accessed on 10 February 2022).

19. Yildirim, I.Z.; Prezzi, M. Chemical, mineralogical, and morphological properties of steel slag. Adv. Civ. Eng. 2011, 2011, 463633. [CrossRef]

20. Mo, L.; Zhang, F.; Deng, M. Mechanical performance and microstructure of the calcium carbonate binders produced by carbonating steel slag paste under $\mathrm{CO}_{2}$ curing. Cem. Concr. Res. 2016, 88, 217-226. [CrossRef]

21. Wang, X.; Ni, W.; Li, J.; Zhang, S.; Li, K.; Hu, W. Use of $\mathrm{CO}_{2}$ to cure steel slag and gypsum-based material. Energies 2021, 14, 5174. [CrossRef]

22. Humbert, P.S.; Castro-Gomes, J. CO $\mathrm{CO}_{2}$ activated steel slag-based materials: A review. J. Clean. Prod. 2019, 208, 448-457. [CrossRef]

23. Mo, L.; Hao, Y.; Liu, Y.; Wang, F.; Deng, M. Preparation of calcium carbonate binders via $\mathrm{CO}_{2}$ activation of magnesium slag. Cem. Concr. Res. 2019, 121, 81-90. [CrossRef]

24. Mahoutian, M.; Ghouleh, Z.; Shao, Y. Carbon dioxide activated ladle slag binder. Constr. Build. Mater. 2014, 66, $214-221$. [CrossRef]

25. Mahoutian, M.; Shao, Y.; Mucci, A.; Fournier, B. Carbonation and hydration behavior of EAF and BOF steel slag binders. Mater Struct. 2014, 3075-3085. [CrossRef]

26. Polettini, A.; Pomi, R.; Stramazzo, A. Carbon sequestration through accelerated carbonation of BOF slag: Influence of particle size characteristics. Chem. Eng. J. 2016, 298, 26-35. [CrossRef]

27. Li, J.; Ni, W.; Wang, X.; Zhu, S.; Wei, X.; Jiang, F.; Zeng, H.; Hitch, M. Mechanical activation of medium basicity steel slag under dry condition for carbonation curing. J. Build. Eng. 2022, 50, 104123. [CrossRef]

28. Chang, J.; Xiong, C.; Zhang, Y.; Wang, D. Foaming characteristics and microstructure of aerated steel slag block prepared by accelerated carbonation. Constr. Build. Mater. 2019, 209, 222-233. [CrossRef]

29. Cadore, D.E.; Angulski da Luz, C.; Farias de Medeiros, M.H. An investigation of the carbonation of alkaline activated cement made from blast furnace slag generated by charcoal. Constr. Build. Mater. 2019, 226, 117-125. [CrossRef]

30. Wang, X.; Ni, W.; Li, J.; Zhang, S.; Li, K. Study on Mineral Compositions of Direct Carbonated Steel Slag by QXRD, TG, FTIR, and XPS. Energies 2021, 14, 4489. [CrossRef]

31. Wei, X.; Ni, W.; Zhang, S.; Wang, X.; Li, J.; Du, H. Influence of the key factors on the performance of steel slag-desulphurisation gypsum-based hydration-carbonation materials. J. Build. Eng. 2022, 45, 103591. [CrossRef]

32. Humbert, P.S.; Castro-Gomes, J.P.; Savastano, H. Clinker-free $\mathrm{CO}_{2}$ cured steel slag based binder: Optimal conditions and potential applications. Constr. Build. Mater. 2019, 210,413-421. [CrossRef]

33. Nielsen, P.; Boone, M.A.; Horckmans, L.; Snellings, R.; Quaghebeur, Q. Accelerated carbonation of steel slag monoliths at low $\mathrm{CO}_{2}$ pressure-microstructure and strength development. J. $\mathrm{CO}_{2}$ Util. 2020, 36, 124-134. [CrossRef]

34. Wang, D.; Chang, J.; Ansari, W.S. The effects of carbonation and hydration on the mineralogy and microstructure of basic oxygen furnace slag products. J. $\mathrm{CO}_{2}$ Util. 2019, 34, 87-98. [CrossRef]

35. He, Z.; Wang, S.; Mahoutian, M.; Shao, Y. Flue gas carbonation of cement-based building products. J. CO 2 Util. 2020, 37, 309-319. [CrossRef]

36. Wang, C.; Liang, Q.; Wang, Y.; Ni, W.; Qiao, C. Experimental study on perparation of autoclaved aerated concrete with iron ore tailings in Dashihe Iron Ming of Shougang. Met. Mine 2013, 2, 4-8.

37. Li, J.; Hitch, M.; Power, I.M.; Pan, Y. Integrated mineral carbonation of ultramafic mine, A review. Minerals 2018, 8, 147. [CrossRef]

38. Li, J.; Hitch, M. Mechanical activation of magnesium silicates for mineral carbonation, a review. Miner. Eng. 2018, 128, 69-83. [CrossRef]

39. $\mathrm{Li}$, J.; Hitch, M. Carbon dioxide adsorption isotherm study on mine waste for integrated $\mathrm{CO}_{2}$ capture and sequestration processes. Powder Technol. 2016, 291, 408-413. [CrossRef] 
40. Power, I.M.; Harrison, A.L.; Dipple, G.M.; Wilson, S.A.; Kelemen, P.B.; Hitch, M.; Southam, G. Carbon mineralization: From natural analogues to engineered systems. Rev. Mineral. Geochem. 2013, 77, 305-360. [CrossRef]

41. Unluer, C.; Al-Tabbaa, A. The role of brucite, ground granulated blastfurnace slag, and magnesium silicates in the carbonation and performance of $\mathrm{MgO}$ cements. Constr. Build. Mater. 2015, 94, 629-643. [CrossRef]

42. Li, J.; Hitch, M. Characterization of the microstructure of mechanically-activated olivine using X-ray diffraction pattern analysis. Miner. Eng. 2016, 86, 24-33. [CrossRef]

43. Li, J.; Hitch, M. Ultra-fine grinding and mechanical activation of mine waste rock using a planetary mill for mineral carbonation. Int. J. Miner. Process. 2017, 158, 18-26. [CrossRef]

44. Wang, Q.; Yang, J.; Yan, P. Cementitious properties of super-fine steel slag. Powder Technol. 2013, 245, 35-39. [CrossRef]

45. Li, J.; Hitch, M. Structural and chemical changes in mine waste mechanically-activated invarious milling environments. Powder Technol. 2017, 308, 13-19. [CrossRef]

46. Li, X.; Hao, J. Orthogonal test design for optimization of synthesis of super early strength anchoring material. Constr. Build. Mater 2018, 181, 42-48. [CrossRef]

47. Li, Z.; He, Z.; Chen, X. The Performance of Carbonation-Cured Concrete. Materials 2019, 12, 3729. [CrossRef] [PubMed]

48. Wang, Q.; Yan, P. Hydration properties of basic oxygen furnace steel slag. Constr. Build. Mater. 2010, 24, 1134-1140. [CrossRef]

49. Chen, Z.; Li, R.; Zheng, X.; Liu, J. Carbon sequestration of steel slag and carbonation for activating RO phase. Cem. Concr. Res. 2021, 139, 106271. [CrossRef]

50. Wilson, S.A.; Raudsepp, M.; Dipple, G.M. Verifying and quantifying carbon fixation in minerals from serpentine-rich mine tailings using the Rietveld method with X-ray powder diffraction data. Am. Mineral. 2006, 91, 1331-1341. [CrossRef]

51. Harrison, A.L.; Dipple, G.M.; Power, I.M.; Ulrich Mayer, K. Influence of surface passivation and water content on mineral reactions in unsaturated porous media: Implications for brucite carbonation and $\mathrm{CO}_{2}$ sequestration. Geochim. Cosmochim. Acta 2015, 148, 477-495. [CrossRef]

52. Viti, C. Serpentine minerals discrimination by thermal analysis. Am. Mineral. 2010, 95, 631-638. [CrossRef]

53. Hrsak, D.; Sucik, G.; Lazic, L. The thermophysical properties of serpentinite. Metalurgija 2008, 47, $29-31$.

54. Wang, Q.; Wang, D.; Zhuang, S. The soundness of steel slag with different free $\mathrm{CaO}$ and $\mathrm{MgO}$ contents. Constr. Build. Mater. 2017, 151, 138-146. [CrossRef]

55. Smarzewski, P. Influence of basalt-polypropylene fibres on fracture properties of high performance concrete. Compos. Struct. 2019, 209, 23-33. [CrossRef] 